\title{
NUTRIENT VALUE OF LANDFILL LEACHATE ON THE GROWTH OF Brassica rapa $L$.
}

\author{
Alaribe, Frank O. and Agamuthu, P.* \\ Institute of Biological Sciences, Faculty of Sciences, University of Malaya, 50603 Kuala, Lumpur, Malaysia. \\ *agamuthu@um.edu.my Telephone: 60379676756 Facisimile: 60379674178 (Corresponding author). \\ Received on $11^{\text {th }}$ April 2010, accepted in revised form $21^{\text {st }}$ July 2010.
}

\begin{abstract}
Leachate from Ampar Tenang landfill was characterized and then treated with ferric chloride. Treated leachate was used at different dilution levels as biofertilizer for the cultivation of Brassica rapa L. (leafy vegetable). A treatment with inorganic fertilizer at the same $\mathrm{N}$-equivalent as the leachate, and a control (water) were also included. Physical growth parameters (leaf length, leaf width, stem height) and harvest parameters (total number of leaves, root length and dry weights of different plant parts) were determined. The dry-weights of leaf, root and stem in (both) treatments had significantly higher biomass over the control. B. rapa receiving $25 \%$ DTL had the highest specific growth rate for leaf length $(0.53 \mathrm{~mm} / \mathrm{d})$ and leaf width $(0.39 \mathrm{~mm} / \mathrm{d})$. Heavy metal accumulations in B. rapa grown with leachate and in B. rapa bought from the market were compared with the permissible concentration limit of FAO/WHO. Inorganic fertilizer did not give a better fertilizing effect in terms of plant yield and growth than the leachate treatments according to this study, but heavy metal accumulation makes the leachate unfit for fertilization of edible plants like Brassica rapa $\mathrm{L}$.
\end{abstract}

(Keywords: Landfill leachate, irrigation, heavy metal, Brassica rapa L., Specific growth rate.)

\section{INTRODUCTION}

Waste generation is attracting much global attention in recent times due to increasing population, changing consumption patterns, economic development, changing income, urbanization and industrialization. Malaysia, like many other transitory nations, is confronted with solid waste generation and disposal problem; the production of municipal and commercial wastes has reached roughly 11.4 million metric tons/year [1].

In Malaysia, $95 \%$ of the waste collected is disposed off in 260 landfills. Various possible means of eliminating solid urban waste (e.g. by landfilling, composting, incineration, etc.) have shown that the cheapest, in terms of capital cost and exploitation, is landfilling, and it is estimated that the total volume of leachate generated from landfills in Malaysia is about 3.0 million liters per day [2]. This leachate is released into waterways after full or partial treatment. Treated leachate contains nutrients and minerals, and thus it is possible that it can be used for agro-irrigation with some pretreatment.

Cheng and Chu [3] reported on both the positive and detrimental effects of landfill leachate on plant growth, depending on the plant species used and the Therefore, identification and recognition of plant stress in the field would be of great importance in assessing the short-term negative response that is concentration of the leachate. However, Menser and colleagues [4] explained that irrigation with leachate could lead to yield reduction, leaf damage, premature senescence and poor plant survival. In contrast, Liang and colleagues [5] suggested the use of landfill leachate as irrigation water in dry seasons to enhance the growth, survival and stomatal conductance of Acacia confusa, Leucaena leuocephala and Eucalyptus torelliana. Cureton and colleagues [6] reported significantly higher growth in Phalaris arundinacea, Salix babylonica and Populus nigra subjected to leachate application, but some phytotoxicity symptoms, such as brown leaves and necrotic spots, were observed in poplar leaves, while chlorophyll degradation or even complete chlorosis was found in willows.

Informal surveys [7] have indicated that in Harare alone, there are more than 100 hectares of land under horticultural production that utilize wastewater for irrigation of crops, such as maize (Zea mays) and leafy vegetables (Brassica spp.). As a number of factors influence plant vigour in field situation (i.e. soil type, plant species and variety, water quality and irrigation rates, climate, and interaction of two or more factors), predictions of plant growth in leachate irrigation systems are difficult to make.

likely to lead to more severe problems in the long run. Growth rates and biomass production are common indicators of imposed stress [8]. Leaf 
length, leaf width, shoot length, and leaf fluctuating asymmetry, which is a random non-directional deviation from anticipated symmetry, have been proposed as environmental stress indicators [9; 10]. Some consumers consider undamaged, dark green and big leaves as characteristics of good quality leafy vegetables. However, the external morphology of vegetables cannot guarantee safety from contamination. Heavy metals rank high amongst the chief contaminants of leafy vegetables $[7 ; 11 ; 12]$.

Leafy vegetables are expected to grow where there is adequate water supply and the soil is well drained, fertile and preferably alkaline. They prefer a $\mathrm{pH}$ of 5.5 to 7 but tolerate $\mathrm{pH}$ in the range of 4.3 to 7.5 [13]. Shallow cultivation is carried out for weed control. Leafy vegetables prefer a cool moist reasonably fertile soil. The plants being shallowrooted are intolerant of drought; thus they need to be grown in a moist fertile soil for the best quality leaves [14]. Brassicas and mustards need adequate nitrogen and sulfur [15]. An $\mathrm{N}: \mathrm{S}$ ratio from 4:1 to 8:1 works well for Brassica species in general. Brassicas are widely cultivated, especially in China.

However, the search of alternatives to reduce the hazard caused by landfill leachate to the environment, whilst improving soil fertility for sustainable plant/crop production has resulted in studying the recycling possibilities of leachate from landfills. It could be used as a source of water or plant nutrients and as a soil conditioner for crop production.

This study was to analyze the leachate characteristics from the Ampar Tenang landfill, and at the same time to evaluate the fertilizer value compared with conventional inorganic fertilizer. More so, the pollution impacts based on the heavy metal content in the soil and in the test plant, Brassica rapa L., were compared with The Ministry of Agriculture, Fisheries and Forest (MAFF) United Kingdom and FAO/WHO permissible concentration standard.

\section{MATERIAL AND METHODS}

\section{Site, leachate collection and description}

The Ampar Tenang landfill in Sepang, Selangor, Malaysia, was opened in the year 2000, and has been managed by Alam Flora Sdn Bhd, a waste management company in Malaysia. The 4-ha open landfill was for about 150 metric tons of domestic waste generated daily in Sepang; located in the southern part of the state of Selangor. Leachate from this landfill is discharged into the nearby environment and ponds.

Leachate analysis included: $\mathrm{pH}$ and conductivity, measured using a $\mathrm{pH}$ and conductivity probe (Hanna Model, No. 8033). Total suspended solids (TSS) and colour were determined using a spectrophotometer, HACH Model (DR/4000). $\mathrm{BOD}_{5}, \mathrm{COD}$ and total $\mathrm{N}$ were analysed according to the standard methods of APHA, AWWA, and WEF [16] while heavy metals were determined using the digested leachate by inductively coupled plasma optical emission spectrometry (ICP-OES).

The chemical treatment of the leachate was done by using a Jar Test [a six-paddle flocculator, from Stuart Scientific (Flocculator SW1) equipped with 6 beakers of $500 \mathrm{~mL}$ each]. Iron (III) chloride at $4 \mathrm{~g} / \mathrm{L}$ in solid state was used as effective coagulant dosage for raw leachate at $\mathrm{pH} 7$ [17], and the filtrate was used as biofertilizer for fertigation.

\section{Growth conditions, Experimental design and treatments}

This experiment was conducted under a netted plant shelter with dimensions of $1.2 \mathrm{~m} \times 1.2 \mathrm{~m} \times 3.3 \mathrm{~m}$ to protect the treatments from direct rain and sunlight. Brassica rapa L. was grown in free-draining 4-L plastic bags containing $5 \mathrm{~kg}$ of black soil per plastic bag. Seeds were first sown in germination pots which received daily irrigation from water sprinklers. At 6 days after germination, uniform seedlings were selected and transplanted at a rate of two plants per bag $(0.2 \mathrm{~m} \times 0.2 \mathrm{~m})$, spaced $8 \mathrm{~cm}$ apart to reduce inter-plant competition for nutrients. All plants were well-watered daily until leachate application began on the $19^{\text {th }}$ day after seed germination. At this time, the plants had on average $3.5 \mathrm{~cm}$ expanded leaf length, $2.5 \mathrm{~cm}$ leaf width, $2.8 \mathrm{~cm}$ root length by destructive sampling and $1.0 \mathrm{~cm}$ stem height.

Nine treatments containing two plants per bag with four replicates in a randomized complete block (RCB) design with stringent elimination of weeds were imposed. Both $100 \%$ raw and treated leachate had the same total nitrogen content $(0.090 \% \mathrm{~N})$, while the 75 to $12.5 \%$ diluted treated leachate (DTL) contained 0.068 to $0.012 \% \mathrm{~N}$. The $\mathrm{N}$ content of $50 \%$ DTL and $100 \%$ Inorganic Fertilizer (IF) was standardized at $0.045 \%$ N. For each treatment, leachate application rate of $200 \mathrm{~mL}$ was initially (applied) by dripping twice a day (before 8AM and after 5PM) until the plants were more expanded, at which time fertigation was increased- $250 \mathrm{~mL}$ 
(twice a day) because of higher evapotranspirattion. Total leachate treatment period took 36 days. No pesticide was applied to all the plants till the end of the experiment.

After the $56^{\text {th }}$ day (which is equivalent to 36 consecutive days of leachate application), the plants were harvested by uprooting. Fresh weights of the separated leaves, stems and roots were determined as well as the total leaf number (TLN). The leaf length (LL), leaf width (LW) and stem height (SH) were measured prior to harvesting while the root length was measured after harvest.

The leaves, stems and roots were then dried at $70^{\circ} \mathrm{C}$ in a forced draft oven (GO-251) for 3 days until constant weight. The dry matter yield was then determined. All data generated were subjected to statistical analysis using one-way ANOVA of the software SPSS version 17.0. The specific growth rate (SGR) for leaf length, leaf width, root length and stem height was determined as follows [18; 19]:

Specific growth rate, $\left.S G R=\frac{\ln L_{2}}{t_{2}-t_{1}} \frac{\ln L_{1}}{(m m / d}\right)$

where $\mathrm{L}_{1}=$ the initial length at exponential phase, $\mathrm{L}_{2}$ $=$ the final length at exponential phase, $t_{1}=$ the beginning of the selected time interval and $t_{2}=$ the end of the selected time interval.

\section{Heavy Metal Analysis}

After drying, the oven dry weights (DW) of plants and soil were recorded to the nearest gram, and then the samples were individually ground to pass a 2$\mathrm{mm}$ screen in a laboratory mill (Serial no. 39017, Christy and Norris LTD, Chelmsford, England), then a $0.1 \mathrm{~g}$ sample was accurately weighed into a $500-\mathrm{mL}$ volumetric flask [20]. $10 \mathrm{~mL}$ of $65 \% \mathrm{HNO}_{3}$ and $10 \mathrm{~mL}$ distilled water were added into the 500 $\mathrm{mL}$ volumetric flask and refluxed for $10 \mathrm{~min}$ by mounting the flask on the digestion heater (EAM9203 heating mantle) at $105^{\circ} \mathrm{C}$. Another $5 \mathrm{~mL}$ of $65 \% \mathrm{HNO}_{3}$ were added after $15 \mathrm{~min}$ and the mixture digested until the solution became transparent. For the soil samples, $3 \mathrm{~mL}(30 \%) \mathrm{H}_{2} \mathrm{O}_{2}$ and $10 \mathrm{~mL}$ HCL were added while refluxing for 15 min. The resulting solution was cooled, filtered and diluted to $50 \mathrm{~mL}$ using deionized water, and was analyzed for $\mathrm{K}, \mathrm{Ca}, \mathrm{Mg}, \mathrm{Na}, \mathrm{Pb}, \mathrm{Cd}, \mathrm{Se}, \mathrm{Al}$, $\mathrm{Mn}, \mathrm{Cu}, \mathrm{Zn}, \mathrm{Fe}$ and As, using ICP-OES analysis.

\section{RESULTS AND DISCUSSIONS}

\section{Leachate}

The total $\mathrm{N}$ present in the raw leachate sample was $900 \mathrm{mg} / \mathrm{L}$. This high concentration of total nitrogen could be attributed to the breakdown of nitrogenous substances during the organic waste decomposition [21]. The Amper Tenang landfill leachate exhibited typical characteristics of an ageing methanogenic landfill (Table 1). The $\mathrm{BOD}_{5} / \mathrm{COD}$ ratio was between 0.06 and 0.08 , which according to Christensen and colleagues [22] is characteristic of an ageing landfill.

The presence of TSS and Total Solid (TS) in the leachate at high levels was mainly due to the organic and inorganic compounds that were present in the leachate [23]. Among the heavy metals analysed from the leachate, $\mathrm{Cd}$ showed lowest concentration whilst the others were above (Standard B) of the Environmental Quality Act (EQA) 1974.

$\mathrm{Cd}$ content was reduced by about $100 \%, \mathrm{Al}$ by $64.4 \%, \mathrm{Fe}$ by $51.9 \%, \mathrm{~Pb}$ by $82 \%, \mathrm{Cu}$ by $56.8 \%$ and $\mathrm{Zn}$ by $96.6 \%$ after the leachate were treated with $4 \mathrm{~g} / \mathrm{L}$ of $\mathrm{FeCl}_{3}$ at $\mathrm{pH} 7$. Hamidi and colleagues [24] found that the reduction of all parameters was greater with an increased dosage of coagulant (200 $\mathrm{mg} / \mathrm{L}$ of $\mathrm{FeCl}_{3}$ ), such as the removal of colour, turbidity and suspended solids.

However, $\mathrm{FeCl}_{3}$ was able to remove $85 \%$ of $\mathrm{Pb}$, $88 \%$ of $\mathrm{Cu}, 90 \%$ of $\mathrm{Al}$, and $92 \%$ of $\mathrm{Zn}$ at the optimum dosage of $4 \mathrm{~g} / 500 \mathrm{~mL}$ [25]. Jayabala [26] reported a reduction of $\mathrm{Cd}$ by $83.3 \%$ at $60 \mathrm{mg} / \mathrm{L}$ $\mathrm{FeCl}_{3}$. The best removal capacities for TSS was up to $80 \%$ at $1.5 \mathrm{~g} / \mathrm{L}$ (without $\mathrm{pH}$ adjustment) when coagulants were added to stabilize the leachate [27].

\section{Plant physical growth assessment}

The cultivated Brassica rapa survived till harvest, and common symptoms of soil salination, such as chlorosis and leaf burn, were not observed in the plants irrigated with different leachate concentrations. The plants receiving $25 \%$ diluted treated leachate (DTL) produced significantly longer leaves $(23.17 \pm 0.577 \mathrm{~cm})$ than the other treatments (Table 2), at a high probability level of $\mathrm{p}<0.05$.

The same treatment also gave wider leaves which were 1.36 and 3.23 times higher than those of the plants receiving inorganic fertilizer $[100 \% \mathrm{IF}$ $\left.\left(\mathrm{N}_{15}: \mathrm{P}_{15}: \mathrm{K}_{15}\right)\right]$ and the control at $\mathrm{p}<0.05$. A possible explanation to this may be that $25 \% \mathrm{DTL}$ was optimum in satisfying the nutrient requirement for leaf expansion [28; 19].

Specific growth rate was $0.53 \mathrm{~mm} /$ day leaf length (Table 3). 


\section{Harvest parameter assessment}

\section{Dry biomass weight}

Dry leaf biomass of B.rapa receiving $50 \% \mathrm{DTL}+50 \%$ inorganic fertilizer (IF) was highest at 2.25 and 1.60 times than the control and $100 \%$ IF. Statistical comparison showed that the difference in the means of leaf dry weight for the treatments $50 \% \mathrm{DTL}+50 \% \mathrm{IF}$ and $25 \% \mathrm{DTL}$ were not significantly different at $\mathrm{p}<0.05$. The dry root biomass of the treatment 25\%DTL were 3.16 and 1.70 times higher than the control and 100\%IF (Fig. 1). For dry stem biomass, the control plants were 5.47 times significantly lower than the plants with treatment $100 \% \mathrm{RL} \quad(1.37 \pm 0.176 \mathrm{~g})$ at $\mathrm{p}<0.05$. Applying 100\% raw leachate and 100\% treated leachate resulted in higher dry stem biomasses, and this might be from the effect of the organic content present in the raw leachate [7].

\section{Heavy metals in soil and plants}

The total concentration of the heavy metals present in the soil prior to irrigation with leachate or inorganic fertilizer was below the maximum permissible limits stipulated [29 and 30] (Table 5). The application of leachate generally led to changes in the physicochemical characteristics of the soil, and consequently the heavy metal uptake by vegetables [31]. Comparisons were made between [edible (upper) parts] $1 \mathrm{~cm}$ above soil level of plants which received 50\%DTL and $100 \% \mathrm{IF}$ and a market sample of B.rapa. The concentrations of $\mathrm{Cd}$ in the edible parts of each of the specific treatments including the market control were zero and therefore below the permissible limits of $0.2 \mathrm{mg} / \mathrm{kg}$ [32; 33] (Table 6 and 7).

Traces of $\mathrm{Pb}$ ranging from $0.07-0.09 \mathrm{mg} \mathrm{kg}^{-1}$ were found in the edible parts of plants from treatments $50 \%$ DTL and $100 \%$ IF but there was zero $\mathrm{Pb}$ in the market sample. Nevertheless, the levels were still below the maximum permitted concentration (MPC) of $3 \mathrm{mg} \mathrm{kg}^{-1}$ [33]. Arsenic was present at concentrations below the MPC of $1.0 \mathrm{mg} \mathrm{kg}^{-1}$ [33] proposed by the Food Quality and Standard Control Division, Ministry of Health Malaysia, for heavy metals under the Malaysia Standard *MS 894, conforming to [34, 32 and 33].

$\mathrm{K}, \mathrm{Ca}, \mathrm{Mg}, \mathrm{Na}, \mathrm{Al}$ and $\mathrm{Fe}$ showed higher accumulation in the edible parts of plants receiving the treatment 50\%DTL than in the market sample. This result is in agreement with previous studies $[35 ; 36]$ which showed elevated levels of metals in edible parts of food crops continuously irrigated with wastewater irrigation.

Previous studies [36; 37; 38] demonstrated that plants grown using leachate-irrigated soils were generally contaminated with heavy metals, which pose a major health concern. Our results reveal that roots of $B$. rapa receiving both the treatments $50 \% \mathrm{DTL}$ and $100 \% \mathrm{IF}$ accumulated more $\mathrm{Pb}$ than their corresponding edible parts. Also, several studies have shown that most of the absorbed $\mathrm{Pb}$ remains in the roots [39].

Generally, B.rapa has higher mineral accumulation tendencies in the leaf region. In this study, concentrations of $\mathrm{K}, \mathrm{Ca}, \mathrm{Mg}, \mathrm{Na}, \mathrm{Al}$ and $\mathrm{Fe}$ were the most dominant minerals present. Lead and cadmium were the most insignificant heavy metals found in the plant tissues according to our results.

\section{General Statistics Information}

The various treatments are statistically significant from the control and some are different from one another using the Least Significant Difference (LSD).

\section{CONCLUSION}

From the results of this study, it is confirmed that landfill leachate is as effective as inorganic fertilizers as a source of nutrients for Brassica rapa. However, the presence of heavy metals (which might be harmful to human health) in the leachate, which were accumulated by plants receiving leacheate-irrigation treatments, renders the leachate unfit for irrigating edible plants like B. rapa. The leachate can, however, be utilized as biofertilizer for non-edible plants, such as ornamentals and timber species. When compared with the FAO/WHO standard, the heavy metal accumulation in some of the leachate-grown plants was below the permissible concentration but still at levels generally higher than in the market sample control.

\section{ACKNOWLEDGEMENT}

This study was financially supported by a grant [IPPP/PDiT/Geran (PPP)/2008B/15] from the "IPPP-University of Malaya Malaysia", and the experiment was done at the Solid and Hazardous Waste Laboratory, Institute of Graduate Studies, University of Malaya. The authors wish to thank the grant provider and also their graduate student colleagues who supported this research work. 
Table 1: Characteristics of Ampar Tenang Landfill leachate compared with Standards A and B of Environmental Quality Act (EQA) 1974.

\begin{tabular}{|c|c|c|c|c|}
\hline \multirow[t]{2}{*}{ Parameter } & \multirow[t]{2}{*}{ Unit } & \multirow{2}{*}{$\begin{array}{c}\text { Ampar Tenang } \\
\text { Landfill Leachate } \\
\text { (untreated) }\end{array}$} & \multicolumn{2}{|c|}{$\begin{array}{l}\text { EQA } 1974 \\
\text { STANDARD }\end{array}$} \\
\hline & & & $\mathbf{A}$ & $\mathbf{B}$ \\
\hline Temperature & ${ }^{\circ} \mathrm{C}$ & 30 & 40 & 40 \\
\hline $\mathrm{pH}$ & - & $6.12-7.04$ & $6.0-9.0$ & $5.5-9.0$ \\
\hline $\mathrm{BOD}_{5}$ & $\mathrm{mg} / \mathrm{L}$ & $202-216$ & 20 & 50 \\
\hline COD & $\mathrm{mg} / \mathrm{L}$ & $2500-3800$ & 50 & 100 \\
\hline $\mathrm{BOD}_{5} / \mathrm{COD}$ ratio & $\mathrm{mg} / \mathrm{L}$ & $0.06-0.08$ & N.A & N.A \\
\hline Turbidity & FAU & $950-1570$ & N.A & N.A \\
\hline Sulphate & $\mathrm{mg} / \mathrm{L}$ & $22-420$ & N.A & N.A \\
\hline Total N & $\mathrm{mg} / \mathrm{L}$ & 900 & 50 & 100 \\
\hline Total Solids & $\mathrm{mg} / \mathrm{L}$ & $1716-1720$ & N.A & N.A \\
\hline TSS & $\mathrm{mg} / \mathrm{L}$ & $12.5-14.5$ & N.A & N.A \\
\hline TDS & $\mathrm{mg} / \mathrm{L}$ & $332-330$ & N.A & N.A \\
\hline Conductivity & $\mathrm{ms} / \mathrm{cm}$ & $8.10-16.10$ & N.A & N.A \\
\hline Salinity & $\mathrm{mg} / \mathrm{L}$ & $0.2-0.5$ & N.A & N.A \\
\hline Colour & ADMI value & 15310- 15390 & N.A & N.A \\
\hline K & $\mathrm{mg} / \mathrm{L}$ & $350-800$ & N.A & N.A \\
\hline $\mathrm{Ca}$ & $\mathrm{mg} / \mathrm{L}$ & $20-150$ & N.A & N.A \\
\hline $\mathrm{Mg}$ & $\mathrm{mg} / \mathrm{L}$ & $15-22$ & N.A & N.A \\
\hline $\mathrm{Na}$ & $\mathrm{mg} / \mathrm{L}$ & $550-800$ & N.A & N.A \\
\hline $\mathrm{Pb}$ & $\mathrm{mg} / \mathrm{L}$ & $0-0.50$ & 0.01 & 0.5 \\
\hline $\mathrm{Cd}$ & $\mathrm{mg} / \mathrm{L}$ & $0.0001-0.01$ & 0.01 & 0.02 \\
\hline $\mathrm{Se}$ & $\mathrm{mg} / \mathrm{L}$ & $1.30-1.90$ & N.A & N.A \\
\hline $\mathrm{Al}$ & $\mathrm{mg} / \mathrm{L}$ & $13.0-25.0$ & N.A & N.A \\
\hline $\mathrm{Mn}$ & $\mathrm{mg} / \mathrm{L}$ & $4.0-9.5$ & 0.2 & 1.0 \\
\hline $\mathrm{Cu}$ & $\mathrm{mg} / \mathrm{L}$ & $0.05-0.44$ & 0.2 & 1.0 \\
\hline $\mathrm{Zn}$ & $\mathrm{mg} / \mathrm{L}$ & $1.20-3.5$ & 1.0 & 1.0 \\
\hline $\mathrm{Fe}$ & $\mathrm{mg} / \mathrm{L}$ & $13.0-17.10$ & 1.0 & 5.0 \\
\hline As & $\mathrm{mg} / \mathrm{L}$ & $0-0.60$ & 0.05 & 0.1 \\
\hline
\end{tabular}


Malaysian Journal of Science 29 (2): 119-128 (2010)

Table 2: Comparison of leaf length (LL), leaf width (LW), stem height (SH) and total leaf number (TLN) for Brassica rapa $L$.

\begin{tabular}{|c|c|c|c|c|}
\hline Treatments & $\begin{array}{l}\text { Av. Leaf length } \\
\text { (LL) } \mathrm{cm}\end{array}$ & $\begin{array}{l}\text { Av. Leaf width } \\
\text { (LW) cm }\end{array}$ & $\begin{array}{c}\text { Av. Stem } \\
\text { height }(\mathrm{SH}) \\
\mathrm{cm}\end{array}$ & $\begin{array}{l}\text { Av. Total leaf } \\
\text { number (TLN) }\end{array}$ \\
\hline $100 \% \mathrm{RL}$ & $19.17 \pm 0.58$ zcfg & $9.00 \pm 0.87 \mathbf{z}$ & $2.43 \pm 0.32 \mathbf{z}$ & $\begin{array}{c}16.17 \pm 1.89 \\
\text { zdeh }\end{array}$ \\
\hline $100 \% \mathrm{TL}$ & $19.50 \pm 1.32 \mathbf{z c f g h}$ & $9.83 \pm 1.16 \mathbf{z h}$ & $2.23 \pm 0.32 \mathbf{x}$ & $\begin{array}{c}18.67 \pm 1.61 \\
\text { zcdefh }\end{array}$ \\
\hline $75 \%$ DTL & $15.72 \pm 1.11 \mathbf{z}$ & $8.33 \pm 1.26 \mathbf{z}$ & $2.43 \pm 0.42 \mathbf{z}$ & $14.33 \pm 0.76 \mathbf{z}$ \\
\hline $50 \% \mathrm{DTL}$ & $19.00 \pm 1.80 \mathbf{z c f}$ & $9.00 \pm 0.50 \mathbf{z}$ & $2.27 \pm 0.31 \mathbf{x}$ & $12.00 \pm 1.32 \mathbf{z}$ \\
\hline $25 \%$ DTL & $23.17 \pm 0.58$ zybcdfgh & $10.33 \pm 0.29$ zch & $2.30 \pm 0.36 \mathbf{x}$ & $12.33 \pm 1.04 \mathbf{z}$ \\
\hline $12.5 \% \mathrm{DTL}$ & $15.67 \pm 1.04 \mathbf{z}$ & $9.33 \pm 1.44 \mathbf{z}$ & $2.17 \pm 0.38 \mathbf{x}$ & $15.17 \pm 2.36$ zde \\
\hline $50 \% \mathrm{DTL}+50 \% \mathrm{IF}$ & $16.83 \pm 2.02 \mathbf{z}$ & $9.17 \pm 1.16 \mathrm{z}$ & $2.50 \pm 0.87 \mathbf{x}$ & $\begin{array}{c}16.33 \pm 1.61 \\
\text { zdeh }\end{array}$ \\
\hline $100 \% \mathrm{IF}$ & $17.00 \pm 1.50 \mathbf{z}$ & $7.67 \pm 0.76 \mathbf{z}$ & $2.50 \pm 0.87 \mathbf{x}$ & $13.23 \pm 1.66 \mathbf{z}$ \\
\hline $\mathrm{dH}_{2} \mathrm{O}$ (Control) & $7.17 \pm 0.58$ & $4.50 \pm 1.80$ & $1.50 \pm 0.50$ & $8.33 \pm 0.76$ \\
\hline
\end{tabular}

Levels of significance $\mathrm{p}>0.05$ at $\mathrm{F}=35.256 \quad \mathrm{p}>0.05$ at $\mathrm{F}=7.035 \quad \mathrm{p}>0.05$ at $\mathrm{F}=1.03 \quad \mathrm{p}>0.05$ at $\mathrm{F}=11$.

Table 3: Specific growth rate for Brassica rapa $L$. at harvest.

\begin{tabular}{|c|c|c|c|c|}
\hline Treatments & $\begin{array}{c}\text { Leaf length } \\
\text { LL ( } \mathbf{m m} / \mathbf{d})\end{array}$ & $\begin{array}{c}\text { Leaf width } \\
\mathbf{L W}(\mathbf{m m} / \mathbf{d})\end{array}$ & $\begin{array}{c}\text { Root length } \\
\mathbf{R L}(\mathbf{m m} / \mathbf{d})\end{array}$ & $\begin{array}{c}\text { Stem height } \\
\mathbf{S H}(\mathbf{m m} / \mathbf{d})\end{array}$ \\
\hline $100 \% \mathrm{RL}$ & 0.47 & 0.35 & 0.30 & 0.22 \\
$100 \% \mathrm{TL}$ & 0.48 & 0.38 & 0.42 & 0.20 \\
$75 \% \mathrm{DTL}$ & 0.42 & 0.33 & 0.40 & 0.22 \\
$50 \% \mathrm{DTL}$ & 0.46 & 0.35 & 0.38 & 0.20 \\
$25 \% \mathrm{DTL}$ & 0.53 & 0.39 & 0.30 & 0.21 \\
$12.5 \% \mathrm{DTL}$ & 0.42 & 0.37 & 0.40 & 0.19 \\
$50 \% \mathrm{DTL}+50 \% \mathrm{IF}$ & 0.43 & 0.36 & 0.35 & 0.23 \\
$100 \% \mathrm{IF}$ & 0.44 & 0.31 & 0.42 & 0.23 \\
$\mathrm{dH}_{2} \mathrm{O}(\mathrm{Control})$ & 0.20 & 0.16 & 0.21 & 0.09 \\
\hline
\end{tabular}




\section{DRYWEIGHT OF LEAF, ROOT AND STEM OF Brassica rapa $L$.}

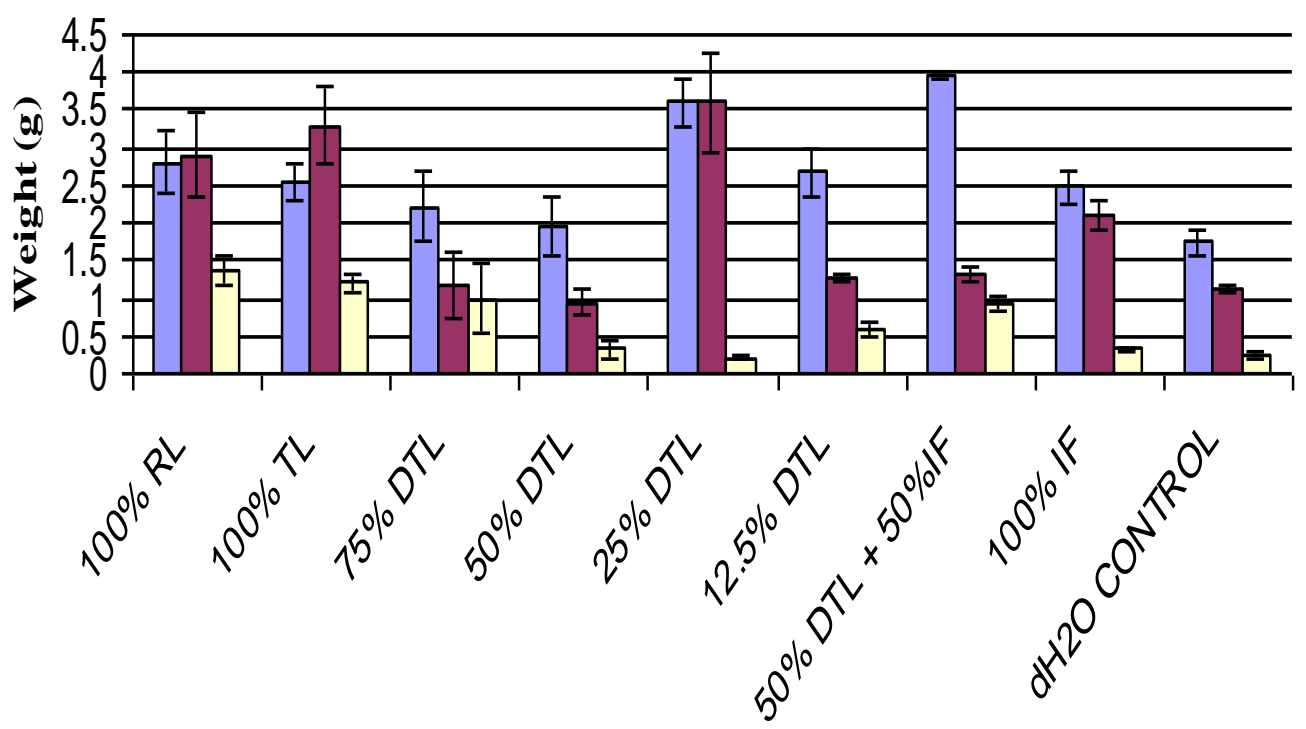

Treatment Levels

Figure 1: Dry weight of various plant parts at harvest under different treatments.

Table 4: Soil quality prior to leachate application compared to MAFF standard.

\begin{tabular}{|c|c|c|}
\hline \multirow{2}{*}{ Heavy } & \multicolumn{2}{|c|}{ Heavy metal in surface soil and MAFF standard } \\
\cline { 2 - 3 } & Prior to leachate application $(\mathrm{mg} / \mathrm{kg})$ & MAFF Standard $(\mathrm{mg} / \mathrm{kg})$ \\
\hline $\mathrm{K}$ & 20.73 & - \\
$\mathrm{Ca}$ & 38.55 & - \\
$\mathrm{Mg}$ & 8.83 & - \\
$\mathrm{Na}$ & 6.68 & - \\
$\mathrm{Pb}$ & $>0.06$ & 0.19 \\
$\mathrm{Cd}$ & $>0.01$ & 0.07 \\
$\mathrm{Se}$ & $>0.05$ & - \\
$\mathrm{Al}$ & 1.85 & - \\
$\mathrm{Mn}$ & 8.85 & - \\
$\mathrm{Cu}$ & 2.71 & 2.9 \\
$\mathrm{Zn}$ & 0.65 & 0.16 \\
$\mathrm{Fe}$ & 30.47 & - \\
$\mathrm{As}$ & $>0.01$ & 0.16 \\
\hline
\end{tabular}


Table 5: Heavy metal content comparisons for treatments 50\%DTL and 100\% IF with both controls for Brassica rapa $\mathrm{L}$. (water and market sample)

\begin{tabular}{|c|c|c|c|c|c|c|c|c|c|c|c|}
\hline \multirow[b]{3}{*}{$\begin{array}{l}\text { Heavy } \\
\text { Metals }\end{array}$} & \multicolumn{11}{|c|}{ Treatment } \\
\hline & \multicolumn{3}{|c|}{$\begin{array}{c}\text { 50\% DTL } \\
(\mathrm{mg} / \mathrm{kg})\end{array}$} & \multicolumn{3}{|c|}{$\begin{array}{c}100 \% \text { IF } \\
(\mathrm{mg} / \mathrm{kg})\end{array}$} & \multicolumn{3}{|c|}{$\begin{array}{c}\mathrm{dH}_{2} \mathrm{O} \text { Control } \\
(\mathrm{mg} / \mathrm{kg})\end{array}$} & \multicolumn{2}{|c|}{$\begin{array}{c}\begin{array}{c}\text { Market Control } \\
(\mathrm{mg} / \mathrm{kg})\end{array} \\
\end{array}$} \\
\hline & \begin{tabular}{|l|} 
Edible \\
Parts
\end{tabular} & Roots & Soil & $\begin{array}{l}\text { Edible } \\
\text { Parts }\end{array}$ & Roots & Soil & $\begin{array}{l}\text { Edible } \\
\text { Parts }\end{array}$ & Roots & Soil & $\begin{array}{l}\text { Edible } \\
\text { Parts }\end{array}$ & Roots \\
\hline \multirow[t]{2}{*}{$\mathbf{K}$} & 42.84 & 31.6 & 1.21 & 62.89 & 3.27 & 1.31 & 0.95 & 1.84 & 1.31 & 12.46 & 11.24 \\
\hline & \pm 4.07 & \pm 4.26 & \pm 0.01 & \pm 3.84 & \pm 2.01 & \pm 0.20 & \pm 0.29 & \pm 0.20 & \pm 0.02 & \pm 2.21 & \pm 3.10 \\
\hline \multirow[t]{2}{*}{$\mathrm{Ca}$} & 18.35 & 14.06 & 5.32 & 41.99 & 2.56 & 6.06 & 0.22 & 1.26 & 5.7 & 6.6 & 3.43 \\
\hline & \pm 2.90 & \pm 3.66 & \pm 0.08 & \pm 3.97 & \pm 0.84 & \pm 0.20 & \pm 0.12 & \pm 0.08 & \pm 0.40 & \pm 1.18 & \pm 0.81 \\
\hline \multirow[t]{2}{*}{ Mg } & 5.65 & 4.85 & 0.92 & 5.74 & 4.96 & 1.83 & 3.06 & 5.73 & 2.04 & 1.78 & 10.85 \\
\hline & \pm 0.03 & \pm 0.45 & \pm 0.04 & \pm 1.39 & \pm 1.22 & \pm 0.11 & \pm 0.79 & \pm 0.54 & \pm 0.02 & \pm 0.21 & \pm 0.23 \\
\hline \multirow[t]{2}{*}{$\mathbf{N a}$} & 41.02 & 30.40 & 5.29 & 15.53 & 2.93 & 6.03 & 2.16 & 2.93 & 2.97 & 5.26 & 3.65 \\
\hline & \pm 3.23 & \pm 4.38 & \pm 0.13 & \pm 1.39 & \pm 1.94 & \pm 0.10 & \pm 0.98 & \pm 0.18 & \pm 0.01 & \pm 2.11 & \pm 0.10 \\
\hline \multirow[t]{2}{*}{$\mathbf{P b}$} & 0.09 & 0.41 & 0.00 & 0.07 & 0.19 & 0.00 & 0.00 & 0.00 & 0.00 & 0.00 & 0.00 \\
\hline & \pm 0.12 & \pm 0.34 & \pm 0.00 & \pm 0.10 & \pm 0.07 & \pm 0.00 & \pm 0.00 & \pm 0.00 & \pm 0.00 & \pm 0.00 & \pm 0.00 \\
\hline Cd & 0.00 & 0.00 & 0.00 & 0.00 & 0.00 & 0.00 & 0.00 & 0.00 & 0.00 & 0.00 & 0.00 \\
\hline \multirow[t]{2}{*}{ Se } & 1.36 & 1.97 & 1.50 & 0.12 & 1.23 & 1.35 & 0.04 & 0.04 & 1.23 & 1.15 & 1.09 \\
\hline & \pm 0.10 & \pm 0.21 & \pm 0.04 & \pm 1.2 & \pm 0.04 & \pm 0.32 & \pm 0.01 & \pm 0.01 & \pm 0.02 & \pm 0.01 & \pm 0.00 \\
\hline \multirow[t]{2}{*}{ Al } & 20.05 & 16.11 & 3.12 & 0.83 & 3.49 & 2.62 & 4.55 & 4.80 & 5.69 & 4.47 & 3.64 \\
\hline & \pm 3.51 & \pm 2.66 & \pm 0.03 & \pm 2.33 & \pm 1.64 & \pm 0.01 & \pm 0.69 & \pm 0.84 & \pm 0.15 & \pm 0.15 & \pm 0.00 \\
\hline \multirow[t]{2}{*}{ Mn } & 0.43 & 0.49 & 0.07 & 0.18 & 0.43 & 0.13 & 0.17 & 0.08 & 0.15 & 1.22 & 0.20 \\
\hline & \pm 0.22 & \pm 0.09 & \pm 0.01 & \pm 0.41 & \pm 0.02 & \pm 0.00 & \pm 0.12 & \pm 0.01 & \pm 0.01 & \pm 0.22 & \pm 0.01 \\
\hline \multirow[t]{2}{*}{$\mathrm{Cu}$} & 0.16 & 0.25 & 0.07 & 0.01 & 0.20 & 0.02 & 0.04 & 0.03 & 0.09 & 0.10 & 0.07 \\
\hline & \pm 0.02 & \pm 0.01 & \pm 0.01 & \pm 0.36 & \pm 0.23 & \pm 0.00 & \pm 0.01 & \pm 0.01 & \pm 0.01 & \pm 0.01 & \pm 0.01 \\
\hline \multirow[t]{2}{*}{$\mathbf{Z n}$} & 0.82 & 1.16 & 0.32 & 0.23 & 1.29 & 0.40 & 0.40 & 0.33 & 1.00 & 0.90 & 0.34 \\
\hline & \pm 0.47 & \pm 0.09 & \pm 0.00 & \pm 1.56 & \pm 0.39 & \pm 0.00 & \pm 0.08 & \pm 0.14 & \pm 0.00 & \pm 0.13 & \pm 0.08 \\
\hline \multirow[t]{2}{*}{$\mathbf{F e}$} & 8.82 & 9.98 & 0.37 & 0.91 & 2.51 & 0.28 & 4.34 & 4.00 & 0.93 & 4.11 & 6.50 \\
\hline & \pm 4.15 & \pm 0.43 & \pm 0.00 & \pm 2.55 & \pm 2.77 & \pm 0.00 & \pm 0.39 & \pm 0.44 & \pm 0.00 & \pm 1.10 & \pm 1.24 \\
\hline \multirow[t]{2}{*}{ As } & 0.08 & 0.08 & 0.12 & 0.03 & 0.06 & 0.12 & 0.07 & 0.08 & 0.17 & 0.09 & 0.09 \\
\hline & \pm 0.03 & \pm 0.02 & \pm 0.00 & \pm 0.08 & \pm 0.02 & \pm 0.02 & \pm 0.03 & \pm 0.01 & \pm 0.03 & \pm 0.00 & \pm 0.01 \\
\hline
\end{tabular}


Table 6: FAO/WHO heavy metal permissible limits in vegetables.

\begin{tabular}{|l|l|l|l|l|l|l|l|l|l|l|l|l|l|}
\hline Heavy metal & K & Ca & Mg & Na & Pb & Cd & Se & Al & Mn & Cu & Zn & Fe & As \\
\hline $\begin{array}{l}\text { FAO/WHO } \\
\text { standard (mg/kg) } \\
\text { dry wt. }\end{array}$ & N.A & 75 & N.A & N.A & $>3$ & 0.2 & N.A & N.A & 0.2 & 40 & 60 & N.A & $\begin{array}{l}>1 . \\
0\end{array}$ \\
\hline
\end{tabular}

Source: FAO/WHO [32, 33, 34].

\section{REFERENCES}

1. Agamuthu, P., Fauziah, S.H., Khidzir, K., (2009). Evolution of Solid Waste Management in Malaysia: impacts and implications of the Solid Waste Bill, 2007. J. Matter Cycle \& Waste Manage (2009) 11: 96-103.

2. Agamuthu, P. and Said, N.A., Al -Abdali (2009). Physico-chemical treatment of Bukit Tagar Sanitary Landfill Leachate using P-Floc 775 and Ferric Chloride.Malaysian Journal of Sci. 28 (2): 187-197.

3. Cheng, C.Y and Chu L.M. (2007). Phytotoxicity data safeguard the performance of the Recipient plants in leachate irrigation. Environmental pollut. 145 (2007) 195-202.

4. Menser, H.A., Infant, W.M., Benneth, O.L., 1983. Spray irrigation with landfill leachate Biocycle 24 (3), 22-25.

5. Liang, J., Zhang, J., Wong, M. H., 1999. Landfill leachate used as irrigation water on landfill sites during dry seasons. In: Wong, M.H., Wong, J.W.C., Baker, A.J.M. (Eds.), Remediation and Management of Degraded Lands. Lewis Publishers, Boca, Raton, pp.305-317.

6. Cureton, P.M., Groenevelt, P.H., McBride, R.A., 1991. Landfill leachate recirculation: effects on vegetation vigor and clay surface cover infiltration. Journal of Environmental Quality 20, 17-24.

7. Mapanda, F., Managwayana, E.N., Nyamangara, J., Giller, K.E., 2005. The effects of long -term irrigation using wastewater on heavy metal contents of soils under vegetable in Harare, Zimbabwe. Agric. Ecosyst. Environ. 107, 151223.

8. Larcher, W. 1995. Physiological Plant Ecology. Springer, Berlin.

9. Alados, C.L., Navarro, T., Escó s, J., Cabezudo, B., Emlem, J.M., 2001. Translational and fluctuating asymmetry as tools to detect stress in stress-adapted and non- adapted plants. International Journal of Plants Sciences 162 (3), 607-616.
10. Zvera, E.L., Kozlov, M.V., Haukioja, E., 1997. Stress responses of Salix borealis to pollution and defoliation. Journal of Applied Ecology 34 (6), 1387-1396.

11. Mangwayana, E.S., 1995. Heavy metals pollution from sewage sludge and effluent of soil and grasses at Crowborough Farm. B.Sc Thesis. University of Zimbabwe, p.63.

12. Nyamangara, J., Mzezewa, J., 1999. The effects of long-term sludge application on $\mathrm{Zn}, \mathrm{Cu}, \mathrm{Ni}$ and $\mathrm{Pb}$ levels in clay loam soil under pasture grass in Zimbabwe. Agric Ecosyt. Environ.73, 199-204.

13. Huxley, A. The New RHS Dictionary of Gardening. 1992. MacMillan Press 1992 ISBN 0-333-47494-5.

14. Larkcom, J. Oriental Vegetables John Murray 1991 ISBN 0-7195-4781-4

15. Grinsted, M. J., Hedley, M. J., White, R. E. and Nye, P. H. 1982. Plant-induced changes in the rhizosphere of rape (Brassica napus var. Emerald) seedlings. I.pH change and the increase in $\mathrm{P}$ concentration in the soil solution. New Phytologist 91:19.

16. Robinson, H.D., (1989). Development of methanogenic condition within landfill. Paper presented at Sardinia 1989: Second International Waste Management and Landfill Symposium, Porto Coute, Sardinia, Italy: 9- 13, October 1989.

17. Said, N. Al Abadali. (2008). Physico-chemical Treatment of Bukit Tagar Sanitary Landfill leachate using Praestol $189 \mathrm{~K}$ and Aluminum Chloride. Dissertation Submitted in Partial Fulfilment of the Requirement for the Degree of Master of Technology (Environmental Management), Institute of Biological Science, Faculty of Science, University of Malaya, Kuala Lumpur. Malaysia pp. 120.

18. Hunt, R., 1982. Plant Growth Curves: the Functional Approach to Plant Growth Analyses. Edward Arnold, London.

19. Dimitriou, I., Aronsson, P., Weih, M., 2006. Stress tolerance of five willow clones after 
irrigation with different amounts of landfill leachate. Bioresource Technology 97: 150-157.

20. Allen, S.E., Grimshaw, H.M., Rowland, A.P., 1986. Chemical analysis: In: Moore, P.D., Chapman, S.B., (Eds), Methods in Plant Ecology. Oxford: Blackwell Scientific Publication, London, pp 285-344.

21. Peter, K., Morton, A., Balaz., Alix, P. Rooker., Anders, Baun., Anna, Ledin. And Thomas, H. Christensen (2002). Present and Long Term Composition of MSW landfill Leachate: A review. Critical Reviews in Environmental Science and Technology, 32 (4): 297-336.

22. Christensen, T.H., Jensen, D.L., Filip, Z., Gron C., and Christen, T.H., (1999). Characterization of the dissolved organic carbon in landfill polluted ground water: Water Res. 23,125.

23. Fauziah, S.H. and Agamuthu, P. (2005). Pollution Impact of MSW Landfill Leachate Malysian Jounal of Science 24: 31-37.

24. Hamidi, A.A., Salina, A., Mohd, N. A., Faridah, A.H., Asaari, M .S. Z.(2007) Colour removal from landfill leachate by coagulation and flocculation processes, J. of Bioresource Technology 98: 218-220.

25. Nor Asikir M. and Agamuthu P. (2007), Characteristics and chemical treatment of Taman Beringin landfill leachate. Malysian J. of Science, 26 (1): 35-42.

26. Jayabala M., M. (2005). Removal of arsenic from municipal landfill leachate. Dissertation $\mathrm{M}$. Tech. (Environmental Mgmt.) Institute of Biological Sciences, University of Malaya. 145 pp.

27. Kargi, F., and Pamukoglu, (2003). Powdered activated carbon added biological treatment of pre-treated landfill leachate in a fed-batch reactor. Biotechnol. Lett. 25:695 699.

28. Aronsson, P., 2000. Nitrogen retention in vegetation filters of short rotation willow coppice. Ph.D. thesis, Silvester 161, Swedish University of Agricultural Sciences.

29. MAFF, 1993. Review of the rules for sewage sludge application to agricultural land. Report of the Independence Scientific Committee PB 1561. United Kingdom Ministry of Agriculture, Fisheries and Forests and Department of the Environment. MAFF Publication, London.

30. MAFF, 2002. Survey of the cadmium contained in agricultural products. MAFF, Japan, pp.1- 45.

31. Monu, A., Bala, K., Shweta, R., Anchal, R., Barinder, K., Neeraj, M., 2008. Heavy metal accumulation in vegetables irrigated with water from different sources. Food Chemistry 111: 811815 .

32. Codex Alimentarius, 2001a. Codex maximum levels for Cadmium in Cereals, Pulses and
Legumes. Joint FAO/WHO Standards, CAC/GL 39-2001.

33. Codex, Alimentarius, 2001b. Maximum levels for Lead. Joint FAO/WHO Standards. Codex STAN 230-2001.

34. Codex, 1995. Codex general standard for contaminants and toxins in foods. Joint FOA/WHO Food Standards Program. Rep. No. CX/ FAC 96/17.

35. Khan, S., Cao, Q., Zheng, Y. M., Huang, Y.Z., \& Zhu, Y.G (2007). Health risks of heavy metals in contaminated soils and food crops irrigated with wastewater in Beijing, China. Envoronment Pollution, 1-7.

36. Liu, W.H., Zhoa, J.Z., Ouyang, Z.Y., Soderlund, L., \& Liu, G.H. (2005). Impacts of sewage irrigation on heavy metals distribution and contamination. Environment International, 31, 805-812.

37. Muchuweti, M., Birkett, J.W., Chiyanga, E., Zvauya, R., Scrimshaw, M.D., \& Lester, J. (2006).Wastewater and sewage sludge in Zimbabwe: Implications for human health. Agriculture, Ecosystem and Environment, (112), 41-48.

38. Sharma, R. K., Agrawal, M., \& Marshall, F. M. (2007).Heavy metal contamination of soil and vegetables in Suburban areas of Varanasi, India. Ecotox. Environ Saf. 66: 258-266.

39. Blaylock, M. J., Huang, J.W., Phytoremediation of Metals. In: Raskin 1, Ensley BD, editors. Phytoremediation of toxic metals: using plants to clean up the environment New York: John Wiley; 2000, p.53-71. 
Malaysian Journal of Science 29 (2): 119-128 (2010) 